STUDI

FRANCESI

\section{Studi Francesi}

Rivista quadrimestrale fondata da Franco Simone

159 (LIII | III) | 2009

Varia

\title{
Lire Nerval au XXI siècle, Invitation au monde nervalien pour les jeunes lecteurs, textes réunis par Huisashi Mizuno
}

\section{Philippe Andrès}

\section{(2) OpenEdition}

Journals

\section{Édition électronique}

URL : http://journals.openedition.org/studifrancesi/7649

DOI : 10.4000/studifrancesi.7649

ISSN : 2421-5856

Éditeur

Rosenberg \& Sellier

\section{Édition imprimée}

Date de publication : 1 décembre 2009

Pagination : 651-652

ISSN : 0039-2944

\section{Référence électronique}

Philippe Andrès, "Lire Nerval au xxı siècle, Invitation au monde nervalien pour les jeunes lecteurs, textes réunis par Huisashi Mizuno », Studi Francesi [En ligne], 159 (LIII | III) | 2009, mis en ligne le 30 novembre 2015, consulté le 09 janvier 2021. URL : http://journals.openedition.org/studifrancesi/7649 ; DOI : https://doi.org/10.4000/studifrancesi.7649

Ce document a été généré automatiquement le 9 janvier 2021.

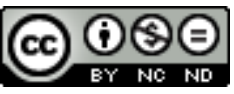

Studi Francesi è distribuita con Licenza Creative Commons Attribuzione - Non commerciale - Non opere derivate 4.0 Internazionale. 


\title{
Lire Nerval au XXI ${ }^{\mathrm{e}}$ siècle, Invitation au monde nervalien pour les jeunes lecteurs, textes réunis par Huisashi Mizuno
}

\author{
Philippe Andrès
}

\section{RÉFÉRENCE}

AA. VV., Lire Nerval au XXI siècle, Invitation au monde nervalien pour les jeunes lecteurs, textes réunis par Huisashi MIZUNO, Kobe-St.Genouph, Société des Études du romantisme au Japon-Librairie Nizet, 2007, «Études du romantisme au Japon» III, pp. 243.

Ce petit volume a peu de chances d'atteindre le but qu'il s'est fixé: rendre accessible la lecture de Nerval aux jeunes lecteurs. Le chercheur peut-il s'improviser pédagogue et vice versa? On peut certes louer la tentative de Jacques BONY, sous forme de saynète consacrée à Sylvie racontée à mes petits-enfants (pp.15-59), mais ne relève-t-elle pas plutôt de la sphère familiale? Comment l'adolescent auquel est censé s'adresser l'auteur de l'article Lire les rêves dans Nerval, peut-il vraiment saisir le jeu intellectuel de Pierre CAMPION quand il affirme: «La conscience de soi est conscience de la multiplicité qui est le moi, lequel a, pour ainsi dire, la responsabilité de se vivre comme étant lui-même pour cette complexité»(p.71)? Cependant parmi les contributions qui sauvent ce volume, remarquons celle de Michel BRIX, Hoax et canards nervaliens (pp.117-133); le critique se livre, en effet, à une fine analyse de l'écriture de la mystification, ce «fruit de l'accouplement du paradoxe et de la fantaisie» (p. 133). Retenons également l'article de Guy BARTHÉLÉMY sur Nerval à la rencontre de l'Orient (pp. 135-152) même si le thème n'est pas nouveau pour les dix-neuviémistes. Françoise sylvos, dans Figures du voyageur excentrique (pp. 175-187), nous invite à visiter les «marges de l'œuvre de Nerval» qui «ne sont pas nettement délimitées» (p. 185). Christian LEROY, pour sa part, dans Folie, humour 
et poésie chez Gérard de Nerval (pp. 189-210) nous propose une synthèse honnête sur la complexité psychique de Nerval à la lumière des travaux de Lelut, entre 1830 et 1850 (p. 203).

2 Finalement, ce volume III des «Études du romantisme au Japon» ne fera pas date dans l'histoire des études nervaliennes. Mais les participants se sont fait, semble-t-il, plaisir. Argument sans doute nécessaire mais peut-être pas suffisant pour transmettre à la jeune génération le goût de la recherche littéraire! 